\author{
Антонюк Олена Ігорівна, \\ кандиАат юриАичних наук, Аоцент, \\ Аоцент кафеАри менеАжменту охорони зАоров'я \\ Національного меАичного університету імені О.О. Богомольця, \\ Аоцент кафедри цивільного права і процесу \\ Аонецького національного університету імені Василя Стуса, \\ Член Правління Української асоціації клінічних досліджень, \\ старший партнер Юридичної фірми “О2"
}

\title{
СУБ'ЄКТИ, ЯКІ МАЮТЬ ПРАВО ДАВАТИ ІНФОРМОВАНУ ЗГОДУ НА УЧАСТЬ У КЛІНІЧНИХ ВИПРОБУВАННЯХ ЛІКАРСЬКИХ उАСОБІB
}

Постановка проблеми. ВіАповіАно Ао ст. 27 Загальної декларації прав ^юАини кожна мюАина має право брати участь у науковому прогресі та користуватися його благом. ОАним з напрямів такого прогресу у медичній сфері $€$ клінічні випробування лікарських засобів.

За ст. 7 Міжнародного пакту про громадянські і політичні права, особа не може бути піддана медичним чи науковим дослідам без її вільної згоди.

Аоктрина інформованої згоди заснована на повазі до кожної мюдини, ії прав на самовизначення, самостійне прийняття рішень, що стосуються її життя та зАоров'я [1, с. 29]. Така властивість отримала назву "автономність рішення пацієнта", якою $€$ самовизначення пацієнта піА час прийняття остаточного рішення, яке стосується його самого [2, с. 69].

у п. 1 Нюрнберзького кодексу 1947 року було передбачено, що добровільна згода мюдини-суб'єкта Аослідження є абсолютно необхіАною. Це означає, що учасник АосліАження повинен: 1) бути юридично уповноважений давати згоду; 2) володіти правом вільного вибору; 3) надавати згоду без втручання або застосування сили, шахрайства, обману, переоцінки інформації або іншої прихованої форми примусу чи насильства; 4) володіти достатніми знаннями і розуміти виклаАену інформацію, щоб мати можливість приймати рішення про згоду в умовах достатньої інформованості про досліАження.
ВіАповідно Ао ст. 4 Європейської хартії прав пацієнтів кожен має право на отримання будьякого роду інформації, яка Аозволить йому (їй) активно брати участь в ухваленні рішень щодо свого зАоров'я; ця інформація $€$ обов'язковою попередньою умовою проведення будь-яких процедур і лікування, вк^ючаючи участь в наукових дослідженнях. У випадках, коли Аля інформованої згоди потрібна присутність законного преАставника, пацієнт - неповнолітній або дорослий, нездатний зрозуміти, що відбувається або висловити свою волю, проте повинен за можливістю брати участь у прийнятті рішень, що стосуються його (iï).

Отримання інформованої згоди віАповіАно Ао ст. 8 Закону України "Про мікарські засоби" та п.п. 1.3, 2.7 Розділу IV Порядку проведення клінічних випробувань лікарських засобів та експертизи матеріалів клінічних випробувань (Аалі Порядок) є обов'язковою умовою проведення кАінічного випробування лікарського засобу.

Отримання такої згоди є однією 3 гарантій невіААільних прав АюАини на життя, охорону зАоров'я, свободу та особисту недоторканість.

Стан АосліАження проблеми. Незважаючи на важливість питання інформованої згоди Аля охорони та захисту прав пацієнта, а також правомірності проведення клінічного випробування, ці питання не були преАметом самостійного наукового досліАження. Питання інформованої згоди досліАжувалися переважно у контексті 
медичного втручання, зокрема, такими вченими, як С.Б. Булеца, М.А. Каменська, В.І. Клименко, М.С. Малеїн, Т.А. Покуленко, В.О. Сакало, І.Я. Сенюта, О.І. Смотров, С.Г. Стеценко, В.Ю. Стеценко, М.М. Хоменко, А.С. Шевченко, та Аеякими іншими.

Проте аналіз нормативного регулювання питань отримання інформованої згоди пацієнта свідчить про наявність Аеяких неузгодженостей, у тому числі з положенням щодо АієзАатності та представництва. Зазначене зумовлює необхідність окремого наукового АосліАження питань інформованої згоди на участь у клінічному випробуванні лікарського засобу.

Мета статті. Метою цього АосліАження є визначення осіб, які можуть приймати рішення щодо залучення іншої ^юАини у клінічне випробування.

ВикиаА основного матеріалу АосліАження 3 повним обгрунтуванням отриманих наукових результатів. У національному законодавстві віАсутня термінологічна єАність щодо назви зазначеної згоди, а також переліку осіб, згода яких $€$ Аостатньою Аля залучення пацієнта у клінічні випробування, як і Аля зАійснення меАичного втручання.

Так, у Законі України "Про мікарські засоби" (ст. 8) використаний термін "згода". Проте у Порядку використовується термін “інформована згода", яка може бути надана як в усній, так і у письмовій формі (п.п. 2.3, 2.6 РозАілу IV).

Інформована згода відповіАно Ао п. 2.1 РозАілу II Порялку - це рішення взяти участь у клінічному випробуванні, яке має бути складено в письмовій формі, Аатоване та піАписане, приймається Аобровільно після належного поінформування про характер клінічного випробування, його значення, вплив та ризик, віАповіАним чином Аокументально оформляється особою, яка спроможна Аати згоду, або ії законним преАставником (близьким родичом). Якщо віАповідна особа неспроможна писати чи читати (п. 1.3 РозАілу IV Порялку), вона може Аати усну згоду в присутності щонайменше одного свіАка, який засвіАчує згоду суб'єкта АосліАження у письмовій інформованій згоді.

Схоже визначення інформованої згоди надане у п. 21 ст. 2 Регламенту Європейського Парламенту та РаАи 536/2014 віА 16 квітня 2014 року про клінічні Аослідження мікарських препаратів (Аалі - Регламент).

Участь свідка в отриманні інформованої згоди також врегульована у п. 4.8.9 Настанови "Лікарські засоби. Належна клінічна практика.
СТ-нм0зу 42-7.0:2008" (Аалі - Настанова). У п. 30 Преамбули Регламенту йдеться також про Аокументування інформованої згоди пацієнта, який не зАатний писати, за допомогою альтернативних способів, наприклаА, через аудіо- чи відеозапис.

3 наведеного визначення випливає, що інформована згода - це рішення взяти участь у клінічному випробуванні, яке було прийнято: 1) Аобровільно; 2) після належного поінформування про характер клінічного випробування, його значення, вплив та ризик; 3) особою, яка спроможна Аати згоду, або її законним представником (близьким родичом); 4) у належній формі.

Отже, у назві такої згоди було піАкреслено, що вона $€$ результатом свідомого вибору належним чином поінформованої особи. Перелік інформації, яка має бути надана пацієнту або (та) іншим нормативно визначеним особам, передбачений у Аодатку 2 ло Порялку, а також у п. 4.8.10 Настанови. У разі порушення вимоги щодо належного інформування, рішення пацієнта про участь у клінічному випробуванні не можна вважати інформованою згодою.

А^я прикладу, у рішенні по справі “Х. проти Аанії ЄСП^ було визнано, що лікування експериментального характеру без згоди пацієнта може у певних випалках розглядатися як порушення ст. 3 "Заборона катування" Конвенції про захист прав ^юАини і основоположних свобоА. Проте це не стосується випаАків проведення за згодою пацієнта операції, в якій мікар використовує новий інструмент [3]. За обставинами цієї справи заявниця, яка звернулася до лікарні 3 метою проведення стерилізації, була поінформована, що результат операції буде майже незворотним, і підписала декларацію про згоду. ПіА час операції хірург використав нову модель затискача, що була запроваджена за три місяці Ао втручання. Через кілька тижнів заявниця дізналась, що вагітна. Згідно з офіційними даними зі 72 випалків стерилізації із застосуванням такого виду затискача - 10 були невАалими. Комісія віАзначила, що запроваАження нового інструменту, який незначною мірою технічно віАрізнявся віА того, що використовувався раніше, не змінило самої процедури операції, мало на меті запобігти побічним ефектам, які вже були відомі медичним працівникам. Комісія не визнала операцію медичним експериментом.

Інакше інформована згода визначена у п. 1.28 Настанови, віАповіАно Ао якого вона $€$ процеАурою, за Аопомогою якої суб'єкт Аобро- 
вільно піАтверАжує свою згоду на участь у клінічному випробуванні після ознайомлення з усіма особливостями АосліАження, які можуть вплинути на його рішення. Вона Аокументально оформляється за Аопомогою підписання і датування форми згоди. ОАнак, якщо інформована згода - це процедура, то цьому не відповідає Аруге речення, аАже форма згоди не може бути документальним оформленням процедури ії піАтверАження. Крім того, у піАп. 4.8.1 ПоряАку йдеться про отримання та Аокументальне оформлення інформованої згоди. Якщо інформована згода - це процедура, то її не можна отримати, а зміст форми такої згоди свідчить про фіксування не процедури, а рішення про участь у випробуванні.

Аля прикладу, у абз. 9 ст. 1 Закону України "Про психіатричну Аопомогу" використаний термін "усвідомлена згода особи", який позначає згоду саме пацієнта. Аля позначення волевиявмення інших осіб стосовно надання психіатричної Аопомоги використаний термін "згода".

Термін "згода" вживається у ст. 284 ЦК України піА час розкриття змісту права на медичну Аопомогу. У ч. 3 ст. 42 «Загальні умови медичного втручання" та у ст. 43 "Згода на медичне втручання" Закону України "Основи законодавства України про охорону зАоров'я" (Аалі - Основи) використане словосполучення "згода інформованого пацієнта". Відповідно Ао ст. 43 Основ така згода необхідна на застосування методів Аіагностики, профілактики та лікування. Щодо пацієнта віком до 14 років (малолітнього пацієнта), а також недієзАатного пацієнта, медичне втручання зАійснюється за згодою їх законних представників. Про близьких родичів пацієнта у цій статті не йдеться.

ПіА інформованою згодою на меАичне втручання у науковій мітературі пропонується розуміти Аобровільне, компетентне прийняття пацієнтом запропонованого варіанта ^ікування, що ґрунтується на одержанні ним повної, об'єктивної і всебічної інформації з приводу майбутнього лікування, його можливих усклаАнень й альтернативних методів лікування [4, с. 161]. Серед критеріїв правомірності “інформованої згоди» називають: інформованість, Аобровільність, компетентність [4, с. 164, 165]; Аійсність, своєчасність, Аобровільність та надання на проведення науково виправданого методу мікування, а за його віАсутності - на застосування експериментального методу медичного втручання [5, с. 76; 6, с. 611]. СліА зауважити, що інформована згода у нормативно визначених випадках може надаватися й іншими особами.
НаприклаА, ЄСП^ було визнано, що рішення про зАійснення лікування всупереч запереченням пацієнта (або його законного представника) свідчить про наявність втручання у право на повагу Ао його приватного життя та право на фізичну недоторканність ("Glass v. the United Kingdom"). Така згода має бути добровільною, ясно висловленою та інформованою [3].

у назві та тексті ст. 43 Основ йдеться про "медичне втручання", поняття якого не було визначено у ст. 3 цього Закону та інших нормативно-правових актах. Ао медичного втручання у науковій мітературі пропонується віАносити, зокрема, аналіз крові, спинномозкову пункцію, сеанс гіпнозу і рентгенологічне АосліАження, прийом пацієнтом будьяких міків та пломбування зуба, піАшкірні ін'єкції та операції з трансплантації органів [7, с. 91].

У ст. 2 проекту Закону «Про правові основи біоетики і гарантії ії забезпечення" медичне втручання визначається більш широко - як будь-яке обстеження, лікування або інша Аія, що пересліАує профілактичну, Аіагностичну, мікувальну або реабілітаційну мету і виконується мікарем або іншим виробником меАичних послуг. СліА зауважити, що клінічні випробування не охоплюються таким визначенням, аАже мають іншу мету.

В.О. Сакало піА медичним втручанням пропонує розуміти весь арсенал засобів практичної меАицини та меАицини наукової (Аослідної), який робить на ^юАину медичний вплив (профілактика, Аіагностика, мікування, реабілітація, Аонорство, наукове Аослідження) [6, с. 612].

Згода пацієнта чи його законного представника на медичне втручання не потрібна мише у разі спільної наявності таких умов: 1) ознаки прямої загрози життю пацієнта; 2) неможливість отримання 3 об'єктивних причин згоАи на втручання віА пацієнта чи його законних представників (ч. 2 ст. 43 Основ).

Наказом М03 України віА 14 нютого 2012 року № 110 у редакції наказу віА 8 серпня 2014 року № 549 затверджена форма Інформованої добровільної згоди пацієнта на проведення Аіагностики, мікування та на проведення операції та знеболення (Форма № 003-6/о) та Інструкція щодо ії заповнення. Форма № 003-6/о підписується пацієнтом або його законним представником, хоча у ії тексті йдеться про згоду пацієнта або його батьків (проте не про опікуна чи піклувальника). Зміст Інструкції щодо ії̈ заповнення не враховує випадки надання згоди не пацієнтом. Так, у п.п 2-4 Інструкції передбачено, що Форма № 003-6/о заповнюється і піАписується пацієнтом. 
У ст. 44 Основ щодо застосування нових метоАів профілактики, Аіагностики, мікування, реабілітації та лікарських засобів, які знаходяться на розгляді в установленому порядку, але ще не Аопущені до застосування, має бути отримана письмова згода: 1) пацієнта; 2) батьків або інших законних представників пацієнта, який не Аосяг 14 років; 3) пацієнта віком віА 14 Ао 18 років та його батьків або інших законних преАставників; 4) пацієнта, цивільна дієздатність якого обмежена, та його піклувальників; 5) законного преАставника пацієнта, визнаного неАієздатним.

Основи (ст. 45) допускають залучення особи у медико-біологічний експеримент на АюАях лише за умови повної інформованості і вільної згоди повнолітньої Аієздатної особи. Забороняється проведення науково-дослідного експерименту на хворих, ув'язнених або військовополонених і терапевтичного експерименту на люАях, захворювання яких не має безпосереднього зв'язку з метою АосліАу. Отже, йАеться про участь у зазначеному експерименті лише повнолітньої повністю Аієздатної особи і лише за її згодою.

ОАнак, поняття "МеАико-біологічний експеримент" у ст. 3 Основ та інших нормативно-правових актах не сформульоване.

Як зауважує І.Я. Сенюта, на національному нормативному рівні Аля позначення меАичних Аослідів використовуються різні словоспомучення: МеАичний АосліА, МеАико-біологічний експеримент, клінічне випробування, АосліА наА ^юАиною. У Аоктрині використовуються й інші, зокрема, медичний експеримент, біомеАичний експеримент, медико-біологічні АосліАження. Найбільш містким вчена вважає поняття “медичний АосліА", що поглинає, зокрема, "клінічні випробування лікарських засобів", своєю чергою "МеАичний АосліА" поглинається роАОвим поняттям "науковий АосліА” [8, с. 43-44].

У ст. 2 проекту Закону «Про правові основи біоетики і гарантії ії забезпечення" біомедичне АосліАження визначається як наукове АосліАження, метою якого є вивчення конкретних фізіологічних, психологічних та інших станів організму мюАини піА впливом факторів, а також апробація нових Аіагностичних, лікувально-профілактичних, реабілітаційних методів, лікарських та інших засобів, проведене у формі клінічного іспиту за участю мюАини в якості випробуваного. Ао них віАнесені і клінічні випробування.

ВіАповіАно Ао ч. 3 ст. 281 ЦК України меАичні, наукові та інші досліди можуть провадитися лише щодо повнолітньої Аієздатної фізичної особи за ії вільною згодою. Окремо зазначено, що клінічні випробування мікарських засобів проводяться віАповіАно Ао закону.

У ст. 8 Закону України "Про лікарські засоби" передбачено, що кмінічні випробування мікарських засобів проводяться за участю повнолітньої АієзАатної особи - пацієнта (Аобровольця) у разі наявності їі письмової згоди на це. Малолітня особа може залучатися до таких випробувань за наявності письмової згоди ї̈ батьків та за умови надання їй віАповідної інформації у Аоступній Аля неї формі, а неповнолітня особа - за ії письмовою згодою та письмовою згодою ї̈ батьків. Отже, згода може бути надана мише батьками (а не будь-якими законними преАставниками, зокрема, опікунами), оскільки забороняється залучення до таких випробувань Аитини, яка позбавлена батьківського піклування, усиновленої Аитини або дитини-сироти.

Не віАповіАає чинному законодавству припис ст. 8 Закону України "Про лікарський засіб", віАповіАно Ао якого клінічні випробування лікарських засобів за участю особи, яка судом визнана недієзАатною або цивільна АієзАатність якої обмежена у зв'язку з психічним захворюванням, можуть проводитися у разі наявності письмової ЗгоАи ї̈ опікунів.

ВіАповіАно Ао ч. 1 ст. 37, ст. 59 ЦК України наА фізичною особою, цивільна дієздатність якої обмежена, встановлюється піклування (а не опіка). Крім того, у разі обмеження Аієздатності $\epsilon$ необгрунтованим позбавлення особи права вирішувати питання участі у кмінічних випробуваннях.

При цьому у ст. 8 Закону України «Про лікарський засіб" передбачається, що пацієнт (Аоброволець) або його законний преАставник повинен отримати інформацію щодо кмінічних випробувань. Використання сполучника "або" свідчить про те, що у разі наявності законного представника, зокрема, піклувальника, особі, Аієздатність якої обмежена, таку інформацію не мають надавати, що не можна визнати прийнятним.

Згінно з п. 2.1 Роздіму II Порядку інформована згода на участь пацієнта у киінічному випробуванні Аається: 1) пацієнтом; 2) законним преАставником пацієнта; 3) близьким родичем пацієнта.

СліА зауважити, що наведене у п. 2.1 Розділу II Порядку визначення інформованої згоди сформумьовано недостатньо коректно, аАже якщо інформована згода $€$ рішенням, то у тих випадках, коли Аопускається ії наАання не самим пацієнтом, а іншими особами, йАеться не про оформлення 
іiі останніми особами, а про прийняття ними рішення щодо участі іншої особи у клінічному випробуванні. НаприклаА, у п. 21 ст. 2 Регламенту інформована згода у випадку неповноліття чи неАієзАатності суб'єктів є Аозволом або згодою їх законного представника на вк^ючення їх у к^інічне АосліАження.

ВіАповіАно Ао п. 1.37 Настанови законним представником $€$ фізична або юридична особа чи інша організація, що має законне право дати віА імені потенційного суб'єкта випробування згоду на участь у клінічному АосліАженні.

У Поряаку цей термін вживається у вужчому значенні, аАже поряд з ним у деяких випадках вживається термін "близькі родичі", які мають право у певних випадках Аавати інформовану згоду, тому підпадають піА наведене у п. 1.37 Настанови визначення "законного представника".

Також слід звернути увагу на те, що перелік близьких родичів, визначений у п. 2.1 РозАілу ІІ Порялку, є ширшим за обраний Аля їх позначення термін і не відповідає наданому у Порядку визначенню близького родича.

Так, близькими родичами визначаються фізичні особи, природний зв'язок між якими ґрунтується на походженні оАин віА одного або віА спільних предків і має правове значення у випаАках, передбачених законодавством; близькими родичами є чоловік (Аружина), батьки, Аіти, рідні брати і сестри.

Перелік близьких родичів є вичерпним, тому виникає питання щодо Аоцільності та точності наведеного переА ним визначення близьких родичів. Так, чоловік і жінка не мають природнього зв'язку, заснованого на походженні - вони $€$ членами сім'ї, а не близькими родичами.

Ао кола осіб, які можуть Аавати у нормативно визначених випадках інформовану згоду на участь пацієнта у клінічному випробуванні, не віднесені особи, які спільно проживають однією сім'єю без реєстрації шлюбу.

Наведений у Порядку перелік близьких родичів $€$ вужчим за той, що міститься у інших нормативно-правових актах, які не стосуються медичної сфери. Аля прикладу, у п. 1 ч. 1 ст. 36 ЦПУ України та ч. 2 ст. 2 Закону України «Про державний захист працівників суду і правоохоронних органів" цей термін охоплює також діла, бабу та внуків. У п. 1 ч. 1 ст. 3 КПК України додатково переАбачені прадіА, прабабка та правнуки.

Аналогічний до зазначеного у п. 2.1. Розділу II Порядку перелік близьких родичів передбачений у ч. 11 ст. 16 Закону України «Про застосування трансплантації анатомічних матеріалів ^юдині", хоча у ч. 1 ст. 1 цього Закону їх перелік $\epsilon$ ширшим (охоплює бабу, Аіла, прабабу, праділа, внуків, правнуків).

НаприклаА, Закон України «Про Аонорство крові та їі компонентів" не Аопускає щодо Аонорства згоди інших, окрім самого Аонора, осіб.

У ч. 4 ст. 7 Закону України «Про психіатричну Аопомогу" передбачено, що методи Аіагностики та мікування і лікарські засоби, що становлять підвищений ризик Аля зАоров'я особи, якій наАається психіатрична Аопомога, застосовуються за усвідомленою згодою особи, яка Аосягла 14 років; щодо особи віком до 14 років - за згоАою їі батьків чи іншого законного представника; щодо недієздатної особи, яка не здатна надати усвідомлену письмову згоду, - за згодою її законного преАставника.

У п. 2.1 РозАілу II Порялку Ао законних преАставників віднесені батьки, усиновлювачі, батьки-вихователі, опікуни, піклувальники, представники закладів, які виконують обов'язки опікунів та піклувальників. Проте у п. 3.3 РозАілу IV Порялку передбачена заборона проведення клінічних випробувань за участю Аитини, позбавленої батьківського піклування, усиновленої Аитини або Аитини-сироти. Тому зазначення сереА законних преАставників усиновлювачів і батьків-вихователів позбавлене правового значення. Такий висновок віАповіАає й ст. 8 Закону України "Про мікарські засоби".

Близькі родичі пацієнта вправі давати інформовану згоду мише за певних підстав. Так, відповідно до п.п. 1.2., 1.3.2, 2.10 РозАілу IV Порядку у випадках, коли до клінічного випробування залучаються пацієнти, які через свій клінічний стан неспроможні особисто Аати інформовану згоду, необхіАно отримати інформовану згоду близьких родичів у разі віАсутності законного представника. у разі неможливості одержання інформованої згоди у пацієнта і відсутності його законного представника (близького родича) залучення таких пацієнтів до клінічного випробування не Аопускається, їм має надаватися медична Аопомога у встановленому порядку.

Цьому нормативному припису суперечить зміст п. 4.8.15 Настанови, який передбачає, що коли неможливо Аістати попереАню згоду суб'єкта Аля вк^ючення його у АосліАження, то суб'єкт або законний преАставник суб'єкта повинні бути поінформовані про дослідження у найкоротший термін, і у них необхідно отримати згоду на продовження випробування та іншу згоду у разі потреб. 
Отже, йдеться про отримання згоди постфактум, що є незаконним.

У п. 2.8 Розділу IV ПоряАку використана така конструкція, як "погодження участі особи у клінічному випробуванні". Зокрема, зауважується: при залученні до клінічного випробування осіб, на участь яких обов'язково потрібне погодження їх батьків / законного представника / близького родича (наприклаА, малолітні, неповнолітні, недієзАатні особи), ці особи інформуються у межах їх розуміння, а неповнолітні власноруч підписують інформовану згоду.

Водночас у п. 4.1. того ж РозАілу IV Поряаку Аля залучення до клінічного випробування недієзАатної особи закріплюється обов'язковість отримання інформованої згоди законного преАставника чи близького родича. ОАнак норма про Аопустимість залучення недієздатного до участі у клінічному випробуванні за згодою близького родича (не опікуна) викликає питання.

НасампереА сліА зауважити на тому, що віАповідно до ст. 8 Закону України "Про лікарські засоби" клінічні випробування лікарських засобів за участю недієзАатної особи можуть провоАитися мише у разі спільної наявності таких умов: 1) мікарський засіб призначений Аля мікування психічних захворювань; 2) наукове обґрунтування переваги можливого успіху зазначених випробувань наА ризиком спричинення тяжких наслідків Аля зАоров'я або життя такої особи; 3) наявність письмової згоди ії опікуна. Тобто на рівні закону єАиною АОПустимою Згодою щоАо участі недієздатного у клінічному випробуванні $€$ згода його опікуна. Тому положення підзаконного акту у частині допустимості залучення недієзАатного Ао участі у клінічному випробувані за згоАою близького родича не піАлягає застосуванню.

НаприклаА, суА піА час вирішення спору у разі невіАповіАності правового акту правовому акту вищої юриАичної сили має віАповіАно Ао ч. 7 ст. 10 ЦПК України застосувати норми правового акту вищої юридичної сили.

Аля прикладу, у ч. 1 ст. 43 Основ передбачено: медичне втручання щодо пацієнта віком до 14 років або недієздатного пацієнта зАійснюється за згодою їхніх законних представників. Тобто про близьких родичів не йдеться. Крім того, саме на опікуна у ч. 1 ст. 67 ЦК України покладений обов'язок Абати про підопічного, про забезпечення його АогляАом та мікуванням.

СліА звернути увагу на те, що у п. 4.1. РозАілу IV Порядку волевиявлення недієздатної особи стосовно участі у клінічному випробуванні також має значення, аАже дослідником, відповіАальним за отримання інформованої згоди, має бути враховано бажання недієздатного пацієнта узяти участь, або віАмовитися віА участі в клінічному випробуванні, або вийти з нього в будь-який момент. Крім того, недієзАатним пацієнтом має бути одержано інформацію про клінічне випробування, пов'язані з ним ризик і користь у формі, Аоступній Аля його розуміння.

у Аодатку 2 Порядку передбачено, що форма інформованої згоди повинна бути підписана законним представником (близьким родичем) у разі участі недієздатних АосліАжуваних, які неспроможні самостійно Аати інформовану згоду. ОАнак така згода має надаватися виключно опікуном.

Не витримує критики й припис Аодатку 2 Порялку, віАповіАно Ао якого у разі залучення недієздатних АосліАжуваних, які неспроможні самостійно Аати інформовану згоду, віАповідно Ао специфіки Аослідження інформована згода має бути отримана у його законного представника (близького родича). По-перше, згінно з ч. 1 ст. 39 ЦК України недієздатною визнається особа, яка внаслідок хронічного, стійкого психічного розладу не зАатна усвідом^ювати значення своїх Аій і (або) керувати ними, тож зазначені обставини виключають спроможність такої особи самостійно та помірковано приймати рішення, яким $€$ його інформована згода. По-друге, специфіка дослідження не може впливати на те, хто має дати інформовану згоду на залучення недієзАатного у клінічне випробування, аАже такою особою за законом є виключно її опікун.

Суперечить положенням чинного законоАавства щодо Аієздатності мюАини припис п. 4.8.12 Настанови, а саме, що стосовно пацієнта з вираженим слабоумством інформована згода має бути надана законним представником. ОАнак у разі відсутності статусу недієздатного у такого пацієнта не може бути законного представника (опікуна). Відповідно Ао ч. 2 ст. 30 ЦК України обсяг цивільної АієзАатності фізичної особи встановлюється цим Кодексом і може бути обмежений виключно у випадках і в порядку, встановлених законом. Отже, він не може бути звужений підзаконним актом, зокрема, наказом МоЗ України віА 16 мютого 2009 року № 95, яким затверАжена Настанова. У п. 20 ст. 2 Регламенту переАбачено, що законним представником є особа чи орган, який відповідно до законодавства держави наділений повноваженнями Аавати інформовану згоду від імені неповнолітнього або недієздатного. 
у Порядку сформульовані такі правила щодо отримання згоди на участь у киінічному випробуванні дитини: 1) має бути надана у Аоступній Аля розуміння Аитини формі письмова та усна інформація про клінічне АосліАження; 2) інформовану згоду на залучення Аитини мають у письмовій формі надати обидва батьки; 3) якщо малолітня Аитина спроможна висловити згоду, то має бути отримана ї̈ усна згода на залучення до киінічного випробування; 4) інформована згода отримується у неповнолітнього пацієнта; 5) протягом доби з дати отримання інформованої згоди на участь Аитини у клінічному випробуванні інформація про ії залучення направляється Ао органів опіки та піклування за місцем постійного проживання Аитини.

СліА зауважити на тому, що орган опіки та піклування не приймає участі у наданні інформованої згоди, його позиція у питанні участі Аитину у клінічному випробуванні не з'ясовується та не має правового значення. Тому насліАки направлення зазначеної інформації, у тому числі негативна позиція цього органу щодо залучення Аитини Ао клінічного випробування, не мають правового значення Аля проведення клінічного випробування.

Висновки та перспективи подальшого розвитку у Ааному напряму. Залучення Ао клінічних випро- бувань пацієнтів за інформованою згодою інших уповноважених осіб допускається, якщо пацієнт не Аосяг повноліття, його АієзАатність обмежена або він визнаний недієздатним, а також якщо він 3 огляду на свій клінічний стан неспроможний особисто Аати інформовану згоАу.

Аналіз норм, що визначають осіб, які Аають згоду на залучення пацієнта у клінічне випробування, свідчить про необхіАність:

- привеАення їх у віАповіАність АО Норм ЩОАО суб'єктного склаАу відносин законного преАставництва. Зокрема, має бути зазначено, що інформована згода отримується у особи, Аієздатність якої обмежена, а також у їі піклувальника;

- виключення з кола осіб, які можуть давати згоду на залучення пацієнта до клінічного випробування, близьких родичів, яким таке право не надане на рівні закону, зокрема, у випадку недієзАатності пацієнта. Аоцільно виключити з кола законних представників усиновлювачів і батьків-вихователів;

- заміни терміну "близькі родичі" терміном "члени сім'ї і близькі родичі", який Аоцільно визначити через наведення вичерпного переліку таких осіб, в якому мають бути також зазначені усиновлювачі.

\section{NITEPATYPA:}

1. Каменська М.А. Актуальні аспекти етики в реаніматології: доктрина інформованої згоди та поняття смерті мозку. Реаніматологія та інтенсивна терапія. 1999. № 1. С. 28-37.

2. Костенко М.С., Хоменко М.М. Інформована згода неповнолітніх осіб при медичному втручанні: проблемні аспекти. Право і суспільство. 2014. № 3. С. 67-72.

3. Захист біомедичних прав людини у Європейському суді з прав людини. URL: http://ukrainepravo.com/international_ law/european_court_of_human_rights/zakhyst-biomedychnykh-prav-lyudyny-u-evropeys\%60komu-sudi-z-pravlyudyny/?month=5\&year=2018 (дата звернення: 08.03.2019).

4. Медичне право України : підручник / С.Г. Стеценко, В.Ю. Стеценко, І.Я. Сенюта ; за заг. ред. С.Г. Стеценка. Київ : Всеукр. асоціація видавців «Правова єдність», 2008. 507 с.

5. Билиця А.Я. Актуальні проблеми виправданого ризику в медицині. Університетські наукові записки. Часопис Івано-Франківськ. ун-ту права імені Короля Данила Галицького. 2010. № 2. С. 70-80.

6. Сакало В.О. Інформована згода на медичне втручання: біоетичний аспект. Форум права. 2012. № 2. C. 609-613 URL: http://www.nbuv.gov.ua/e-journals/FP/2012-2/12cvovba.pdf (дата звернення: 08.03.2019).

7. Драган В.В., Меднис Д.Ю. Оформление информированного согласия на примере ортопедической операции. Крымский журнал экспериментальной и клинической медицины. 2011. Т. 1. № 2. С. 89-97.

8. Сенюта І.Я. Цивільні правовідносини у сфері проведення медичних дослідів. Медичне право. 2018. № 1(21). С. 42-53.

\section{Антонюк Олена Ігорівна \\ СУБ'ЄКТИ, ЯКІ МАЮТЬ ПРАВО ААВАТИ ІНФОРМОВАНУ ЗГОДУ НА УЧАСТЬ У КАІНІЧНИХ ВИПРОБУВАННЯХ МІКАРСЬКИХ ЗАСОБІВ}

У статті досліАжені положення щодо осіб, які уповноважуються надавати інформовану згоду на участь іншої особи у клінічному випробуванні лікарських засобів у разі недосягнення нею повноліття, обмеження їі дієздатності або визнання недієздатною, а також коли пацієнт з огляду на свій клінічний стан неспроможний особисто Аати інформовану згоду. Сформульовані пропозиції стосовно приведення переліку цих осіб у віАповіАність Ао положень щодо АієзАатності та законного преАставництва.

Киючові слова: інформована згода, клінічні випробування, медико-біологічний експеримент, медичне втручання, пацієнт. 


\section{Антонюк Елена Игоревна \\ СУБЪЕКТЫ, ИМЕЮЩИЕ ПРАВО ААВАТЬ ИНФОРМИРОВАННОЕ СОГААСИЕ НА УЧАСТИЕ В КАИНИЧЕСКИХ ИСПЫТАНИЯХ АЕКАРСТВЕННЫХ СРЕАСТВ}

В статье исследованы положения о лицах, уполномоченных Аавать информированное согласие на участие иного мица в клиническом испытании мекарственного средства в случае его несовершеннолетия, ограничения его дееспособности или признания недееспособным, а также в случае, когда пациент в силу своего клинического состояния не может лично Аать информированное согласие. Сформулированы преАложения по приведению перечня Аанных миц в соответствие с положениями о дееспособности и законном представительстве.

Киючевые слова: информированное согласие, клинические испытания, медико-биологический эксперимент, медицинское вмешательство, пациент.

\section{Antoniuk Olena \\ SUBJECTS HAVING THE RIGHT TO GIVE INFORMED CONSENT FOR THE PARTICIPATION IN CLINICAL TRIALS OF MEDICINES}

The author of the article, based on the analysis of the norms of national legislation and international regulatory acts, as well as the positions of the European Court of Human Rights, has studied the provisions concerning persons who are authorized to provide informed consent to participate in clinical trials of other person's medicinal products. This refers to the involvement of patients into clinical trials, who are minors, whose dispositive legal capacity is limited, or who are admitted legally incapable, and those who due to their clinical condition can not personally give informed consent. The author has formulated propositions to bring the list of these persons in accordance with the provisions of the current legislation on dispositive legal capacity of an individual and legal representation. In particular, the author has substantiated the necessity of normative consolidation for obtaining informed consent from both a person whose dispositive legal capacity is limited, and from his tutor to be involved into clinical trials of medicinal products. It has been proved that it is appropriate to exclude close relatives from the range of persons, who have the right to give consent for the involvement of legally incapable patients to participate in clinical trials of medicinal products, since such consent is solely provided by a trustee of legally incapable person.

The author has suggested to exclude adoptive parents and parents-educators from the range of legal representatives of a patient, who may give consent to his involvement for clinical trials, since children deprived of parental care, adopted children or orphans are not allowed to be involved in such trials. The author has proved the expediency of replacing the term "close relatives", which does not cover a husband or a wife of a patient with the term "family members and close relatives" within the Procedure of conducting clinical trials of medicinal products and examinations of the materials of clinical trials. It has been suggested to include adoptive parents into this list. The range of such persons does not include people who live together with one family without registration of a marriage.

Involvement of patients to clinical trials of medicinal products on the basis of informed consent of an unauthorized person is the violation of inherent rights of patients to health and personal integrity.

Key words: informed consent, clinical trials, biomedical experiment, medical intervention, a patient. 